\title{
An update on the distribution of Cobitis paludica (de Buen, 1930) in the NW Iberian Peninsula
}

\author{
Javier Sánchez-Hernández ${ }^{1,}$, Rufino Vieira-Lanero ${ }^{2}$, Sandra Barca ${ }^{2}$, Sergio Silva ${ }^{2}$, Lorena \\ Lago $^{2}$, Pablo Gómez ${ }^{2}$, María del Carmen Cobo ${ }^{2}$ and Fernando Cobo ${ }^{1,2}$
}

${ }^{1}$ Departamento de Zooloxía, Xenética e Antropoloxía Física, Facultade de Bioloxía, Universidade de Santiago de Compostela, Campus Vida s/n 15782 Santiago de Compostela, España.

2 Estación de Hidrobioloxía 'Encoro do Con', Universidade de Santiago de Compostela, Castroagudín, s/n 36617 Vilagarcía de Arousa, España.

* Corresponding author: javier.sanchez@usc.es

Received: 26/06/17 Accepted: 16/01/18

\begin{abstract}
An update on the distribution of Cobitis paludica in the NW Iberian Peninsula

It has long been believed that the southern Iberian spined-loach (Cobitis paludica) was introduced to the northwest of the Iberian Peninsula. This paper updates the distribution of the southern Iberian spined-loach in the NW Iberian Peninsula with six new localities in the rivers Furnia, Hospital, Pego, Pontiñas, Tripes and Ulla, some of which with substantial populations (Pego and Tripes). This study supports the view that the southern Iberian spined-loach is native in the NW Iberian Peninsula, where its populations are mostly small and appear to be very fragmented. It is therefore critical that sampling effort is increased, to improve our knowledge of the species' abundance, distribution and population dynamics.
\end{abstract}

Key words: Cobitidae, Cypriniformes, distribution, endemic species

\section{RESUMEN}

Actualización de la distribución de Cobitis paludica en el noroeste de la Península Ibérica

Durante mucho tiempo se ha creido que la presencia de la colmilleja (Cobitis paludica) en el noroeste de la Península Ibérica se debe a introducciones. Este artículo actualiza la distribución de la colmilleja en el noroeste de la Península Ibérica con seis nuevas localidades en los ríos Furnia, Hospital, Pego, Pontiñas, Tripes y Ulla, algunas de las cuales con sustanciales poblaciones (Pego y Tripes). Este estudio respalda la opinión de que la colmilleja es nativa en el noreste de la Península Ibérica, donde sus poblaciones son en su mayoría pequeñas y parecen estar muy fragmentadas. Por lo tanto, es fundamental aumentar el esfuerzo de muestreo para mejorar nuestro conocimiento sobre la abundancia, la distribución y la dinámica poblacional de la especie.

Palabras clave: Cobitidae, Cypriniformes, distribución, especie endémica 


\section{INTRODUCTION}

The southern Iberian spined-loach, Cobitis paludica (de Buen, 1930), is a fish species endemic to the Iberian Peninsula that tends to inhabit the middle-lower parts of rivers with low current and feeds predominantly on insect larvae, algae and detritus (Perdices \& Doadrio, 1997). This species is listed as vulnerable (VU) in the Spanish Red Data Book due to abundance declines and contractions in distribution (Doadrio, 2001; Doadrio et al., 2011).

The southern Iberian spined-loach is widely distributed in Iberian river basins (the Albufera de Valencia, Aljibre, Alvor, Arade, Barbate, Bullent, Cavado, Ebro, Guadalete, Guadalhorce, Guadalmedina, Guadalquivir, Guadiana, Jara, Jucar, Limia, Lis, Mijares, Miño, Mondego, Nalón, Odiel, Peñíscola, Piedras, Racons, Sado, Samarra, Segura, Serpis, Sizandro, Tagus, Turia, Vega, and some tributaries on the western margin of Douro basin) (Hervella \& Caballero, 1999; Doadrio, 2001; Doadrio \& Perdices, 2005; Doadrio et al., 2011; Perea et al., 2011). It has long been believed that anglers introduced the species to some tributaries of the Duero basin and the NW Iberian Peninsula (Elvira, 1995; Doadrio, 2001; Doadrio et al., 2011). The species was also introduced in the Segura basin, but these populations may be a consequence of a water-transfer scheme between the Tajo and Segura basins (Verdiell-Cubero et al., 2012). The aims of this note are to (i) update the information on the distribution of the southern Iberian spined-loach in the NW Iberian Peninsula, and (ii) discuss whether the species should be considered as introduced or native in the NW Iberian Peninsula.

\section{MATERIAL AND METHODS}

Sampling campaigns were conducted from June to September in 2008 and 2010 in 23 siliceous rivers in Galicia (NW Spain) (Fig. 1). Ten systems (Anllóns, Eo, Lérez, Mandeo, Masma, Mera, Ouro, Sar, Ulla and Umia) were surveyed in 2008, and the international stretch of the River Miño and 12 tributaries (Barxas, Caselas, Deva, Furnia, Hospital, Louro, Pego, Ribadil, Tamuxe, Tea, Termes and Tripes) were surveyed in 2010.

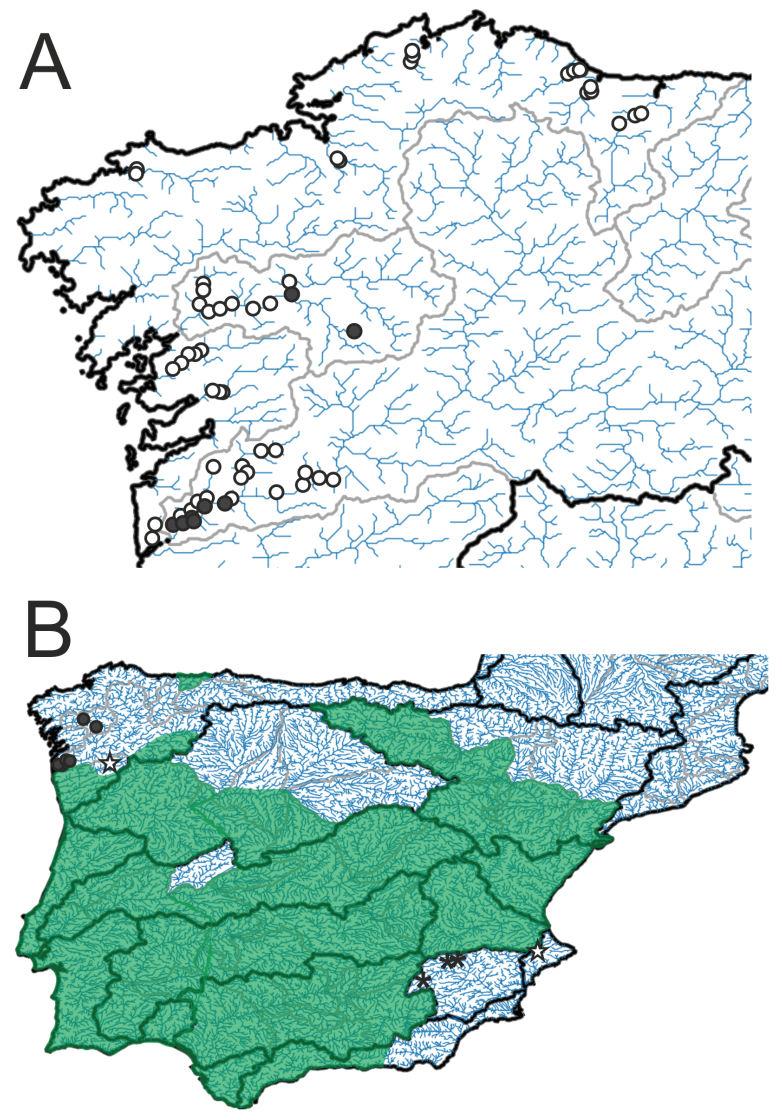

Figure 1. Maps of the NW Iberian Peninsula (A) and Iberian Peninsula (B) showing the distribution of the southern Iberian spined-loach (Cobitis paludica). A = Map of the sampling sites in 23 rivers of Galicia (NW Spain). Presence of the species in dark circles $(\bullet)$ and absence in white circles $(\mathrm{O}) . \mathrm{B}=$ The distribution of the southern Iberian spined-loach. The potential distribution of the southern Iberian spined-loach, based on the work of Perea et al. (2011), is coloured green. Stars ( $t$ ) represent records in the rivers Serpis and Macaco (Perea et al., 2011). Asterisks (*) represent records in the rivers Mundo, Segura and Zumeta (Verdiell-Cubero et al., 2012). Dark circles (•) represent the new records described in this study. River networks (blue lines), river basins (grey lines) and drainage basins (black lines) are shown for both maps (A and B). Mapas del noroeste de la Península Ibérica (A) y de la Península Ibérica (B) mostrando la distribución de la colmilleja (Cobitis paludica). A = Mapa de los puntos de muestreo localizados en 23 ríos de Galicia (NO España). Presencia de la especie en círculos oscuros (•) y ausencia en círculos claros (0). B = Actualización de la distribución de la colimilleja. La distribución potencial de la colmilleja, basada en el trabajo de Perea et al. (2011), se muestra en color verde. Las estrellas (3) representan las citas en los ríos Serpis y Macaco (Perea et al., 2011). Los asteriscos (*) representan las citas en los ríos Mundo, Segura y Zumeta (Verdiell-Cubero et al., 2012). Los círculos oscuros (•) representan las nuevas citas descritas en este estudio. La red hidrográfica (líneas azules), las cuencas fluviales (lineas grises) y las cuencas de drenaje (lineas negras) se muestran para ambos mapas (A y B). 
Fish sampling was conducted using electrofishing (2200-W generator with a single anode of 30 $\mathrm{cm}$ diameter). Densities (ind $/ \mathrm{m}^{2}$ ) of the southern Iberian spined-loach were calculated for the 2010 sampling campaign using the Zippin multiple-pass depletion method (Zippin, 1956). Additionally, opinion surveys were carried out on local (i.e. from Galicia, $n=20$ ) and non-local (i.e. from central Spain, $n=20$ ) anglers in an attempt to establish whether the species has been introduced in NW Spain as a consequence of its use as live bait in recreational fishing (see supplementary information, Appendix 1, available at http://www.limnetica.net/en/limnetica).

\section{RESULTS}

Southern Iberian spined-loach were found in a single locality within the River Ulla basin (Fig. 1), after the capture of two individuals (75 and 77 $\mathrm{mm}$ total length) from Ponte Ledesma (UTM 29T $554286 \mathrm{E} 4738186 \mathrm{~N}$ ). Additionally, the species has been recently reported in the Pontiñas River basin (Lalin, UTM 29T 572493E 4723818N), a tributary of the Deza River in the Ulla basin (see supplementary information, Appendix 2, available at http://www.limnetica.net/en/limnetica). The species was also found in five rivers (Furnia, Hospital, Miño, Pego and Tripes) in the international stretch of the River Miño in 2010, with densities between $0.009 \mathrm{ind} / \mathrm{m}^{2}$ and $0.372 \mathrm{ind} / \mathrm{m}^{2}$ (Furnia and Tripes, respectively). Except three sites in the international stretch of the River Miño (Miño, Pego and Tripes) densities were below $0.10 \mathrm{ind} / \mathrm{m}^{2}$.

Opinion surveys suggested that the southern Iberian spined-loach is unlikely to be used as live bait by local (Galicia, NW Spain) anglers, whereas one angler (5\%) from Central Spain had used the species as live bait (to capture largemouth black bass, Micropterus salmoides (Lacépède, 1802)).

\section{DISCUSSION}

Confirmation of the presence of the southern Iberian spined-loach in the Ulla basin represents a northwestern expansion of its distribution and increases the number of known Galician popula- tions to nine (Furnia, Hospital, Macaco, Miño, Pego, Pontiñas, Tea, Tripes and Ulla). Although the species has previously been recorded in the River Tea (Hervella \& Caballero, 1999), we did not corroborate its presence in our sampling campaigns. Our findings and those of other authors (e.g. Perea et al., 2011), indicate that the species has a wider distribution in the NW Iberian Peninsula, than was previously recognised. The recent records of the species in the Serpis River (Perea et al., 2011) and many sub-basins of the Guadalquivir basin (Fernández-Delgado et al., 2014; Márquez-Rodríguez, 2014) seem to corroborate the idea that populations of the southern Iberian spined-loach may not have been detected in many areas. We suggest that the distribution of this, and maybe other fish species, could be underestimated because of an absence of specific monitoring programmes and inadequate sampling effort (Fernández-Delgado et al., 2014; Nunn et al., 2014; Sánchez-Hernández et al., 2015).

In recent decades, there has been an on-going debate over the status (i.e., native or introduced) of the southern Iberian spined-loach in the Miño basin. The genetic distinctiveness and morphological singularity of the fish in the Miño basin have led some authors to suggest that the populations might constitute a separate species, Cobitis victoriae (De la Cigoña \& Oujo, 1999; but see Doadrio \& Perdices, 2005). However, the lack of a formal description following the International Code of Zoological Nomenclature prohibits the recognition of the species, and C. cf. victoriae should thus remain as nomen dubium (Doadrio \& Perdices, 2005; Silva et al., 2010; Doadrio et al., 2011). Several studies have supported the hypothesis that the southern Iberian spined-loach was introduced, presumably by anglers, to the northwest of the Iberian Peninsula (Doadrio, 2001; Doadrio et al., 2011). While anglers are key agents responsible for the introduction and translocation of fish species (Elvira 1995; Doadrio et al., 2011; Kalous et al., 2013; Moreno-Valcárcel et al., 2013), colonization of Europe by Cobitis spp. (more precisely, Cobitis taenia Linnaeus, 1758) is unlikely to have been driven by anglers because of their apparent lack of economic and recreational importance and low popularity as a live bait in recreational fishing 
(Culling et al., 2006; Kalous et al., 2013). Although the number opinion surveys used in this study may be insufficient to draw strong conclusions, they suggest that the southern Iberian spined-loach has rarely been used as live bait by local (Galicia, NW Spain) anglers. However, this suggestion should be treated with caution, because one angler from Central Spain had used the species as live bait to capture largemouth black bass, a species that is present in the Miño River, but not in the Ulla basin where the southern Iberian spined-loach was unexpectedly found. We posit that it is very likely that local anglers do not target the southern Iberian spined-loach for fishing, and consequently the species is unlikely to have been introduced by anglers in contrast to other species with socio-economic and recreational importance such as, for example, the European catfish Silurus glanis Linnaeus 1758 (e.g. Benejam et al., 2007; Moreno-Valcárcel et al., 2013). However, pathways of introduction other than anglers, such as aquarium trade and intentional release might be responsible of its introduction in NW Iberian Peninsula. Still, we accept the view that the southern Iberian spined-loach should be considered native to the NW Iberian Peninsula, unless future analyses of genetics or pathways of colonization prove a non-native origin.

This study suggests that there is no evidence to support the hypothesis that the southern Iberian spined-loach populations of the NW Iberian Peninsula have been introduced, but most likely highly fragmented and in many cases small. It is therefore critical that sampling effort is increased, to improve our knowledge of the species' abundance, distribution and population dynamics. Monitoring programmes should include endemic species of low socio-economic importance, such as the southern Iberian spined-loach, as their conservation status is of global importance (Nunn et al., 2014; Sánchez-Hernández et al., 2015).

\section{ACKNOWLEDGEMENTS}

We thank many people belonging to the angling club "Valle Iruelas" for their participation in the surveys. We wish to thank Andy Nunn for valuable comments on the manuscript. We appreciate the constructive comments from two anonymous reviewers, which considerably improved the quality of the manuscript. Javier Sánchez-Hernández was supported by a postdoctoral grant from the Galician Plan for Research, Innovation, and Growth (Plan I2C, Xunta de Galicia).

\section{REFERENCES}

BENEJAM, L., J., CAROL, J. BENITO \& E. GARCIA-BERTHOU. 2007. On the spread of the European catfish (Silurus glanis) in the Iberian Peninsula: first record in the Llobregat river basin. Limnetica, 26: 169-171.

CULLING, M. A., K. JANKO, A. BORON, V. P. VASIL'EV, I. M. CÔTE \& G. M. HEWITT. 2006. European colonization by the spined loach (Cobitis taenia) from Ponto-Caspian refugia based on mitochondrial DNA variation. Molecular Ecology, 15: 173-190. DOI: 10.1111/j.1365-294X.2005.02790.x

DE LA CIGOÑA, E. F. \& J. M. OUJO. 1999. Captura, en diversos lugares do Baixo Miño, do peixe chamado por nós barbela do Miño Cobitis victoriae. In: Fauna das augas galegas: E.F. de la Cigoña (ed.): 15-20. Asociación Galega para a cultura e a Ecoloxía (AGCE) \& Instituto Galego de Estudios Mariños (IGEM). Vigo.

DOADRIO, I. 2001. Atlas y Libro Rojo de los Peces Continentales de España. Dirección General de Conservación de la Naturaleza/ Museo Nacional de Ciencias Naturales-CSIC. Madrid.

DOADRIO, I. \& A. PERDICES, 2005. Phylogenetic relationships among the Ibero-African cobitids (Cobitis, Cobitidae) based on cytochrome $\mathrm{b}$ sequence data. Molecular Phylogenetics and Evolution, 37: 484-493. DOI: 10.1016/j.ympev. 2005.07.009

DOADRIO, I., S. PEREA, P. GARZON-HEYDT \& J. L. GONZÁLEZ. 2011. Ictiofauna Continental Española. Bases para su seguimiento. DG Medio Natural y Política Forestal. MARM. Madrid.

ELVIRA, B. 1995. Conservation status of endemic freshwater fish in Spain. Biological Conservation, 72: 129-136. DOI: 10.1016/00063207(94)00076-3

FERNÁNDEZ-DELGADO, C., P. A. RINCÓN, 
L. GÁLVEZ-BRAVO, R. J. DE MIGUEL, F. J. OLIVA-PATERNA, R. MORENO-VALCÁRCEL, E. PINO, A. RAMIRO \& J. P. PEÑA. 2014. Distribución y estado de conservación de los Peces dulceacuícolas del río Guadalquivir. Principales áreas fluviales para su conservación. Ministerio de Agricultura, Alimentación y Medio Ambiente, Confederación Hidrográfica del Guadalquivir.

HERVELLA, F. \& P. CABALLERO. 1999. Inventario piscícola dos ríos galegos. Xunta de Galicia, Santiago de Compostela.

KALOUS, L., J. MUSIL, M. PETRTÝL, T. VAJGLOVÁ, Š. ROMOČUSKÝ \& L. BUŠTA. 2013. The danger in the anglers' bucket: qualitative and quantitative insight into bait fish market in Prague (Czech Republic). Acta Societatis Zoologicae Bohemicae, 77: 27-35.

MÁRQUEZ-RODRÍGUEZ, J. 2014. The first occurrence of Cobitis paludica (de Buen, 1930) in the Corbones River Basin (S Iberian Peninsula). Métodos en Ecología y Sistemática, 9: 49-52.

MORENO-VALCÁRCEL, R., R. J. DE MIGUEL \& C. FERNÁNDEZ-DELGADO. 2013. The first record of the European catfish Silurus glanis Linnaeus, 1758 in the Guadalquivir River basin. Limnetica, 32: 23-26.

NUNN, A. D., L. H. TEWSON, J. D. BOLLAND, J. P. HARVEY \& I. G. COWX. 2014. Temporal and spatial variations in the abundance and population structure of the spined loach (Cobitis taenia), a scarce fish species: implications for condition assessment and conservation. Aquatic Conservation: Marine and Freshwater Ecosystems, 24: 818-830. DOI: 10.1002/aqc.2451.
PERDICES, A. \& I. DOADRIO. 1997. Threatened fishes of the World: Cobitis paludica (De Buen, 1930) (Cobitidae). Environmental Biology of Fishes, 49: 360. DOI: 10.1023/A: 1007332011514

PEREA, S., P. GARZÓN, J. L. GONZÁLEZ, V. C. ALMADA, A. PEREIRA \& I. DOADRIO. 2011. New distribution data on Spanish autochthonous species of freshwater fish. Graellsia, 67: 91-102. DOI: 10.3989/graellsia.2011. v67.032

SÁNCHEZ-HERNÁNDEZ, J., F. COBO \& P.-A. AMUNDSEN. 2015. A simple approach for assigning the conservation status of freshwater fish based on their natural variability - a case study from the Iberian Ecoregion. Fisheries Management \& Ecology, 22: 125-133. DOI: $10.1111 /$ fme.12103

SILVA, S., R. VIEIRA-LANERO, M. J. SERVIA, S. BARCA, M. T. COUTO, S. RIVAS, J. SÁNCHEZ-HERNÁNDEZ, D. NACHÓN, P. GÓMEZ-SANDE, C. MORQUECHO, L. LAGO \& F. COBO. (2010). Datos poblacionales y biométricos de las poblaciones de colmilleja (Cobitis paludica) en los afluentes de la margen española del Baixo Miño. Actas V Simpósio Ibérico Sobre a Bacia Hidrográfica do Rio Minho. Vilanova da Cerveira, Portugal: 157-163.

VERDIELL-CUBERO, D., F. J. OLIVA-PATERNA, A. RUIZ-NAVARRO \& $\mathrm{M}$. TORRALVA. 2012. The first occurrence of Cobitis paludica (de Buen, 1930) in the Segura River Basin (SE Iberian Península). Limnetica, 31: 323-326.

ZIPPIN, C. 1956. An evaluation of the removal method of estimating animal populations. Biometrics, 12: 163-189. 